\title{
Zircon Petrochronology of behemothian porphyry copper systems
}

\author{
ADRIANNA LUIZA VIRMOND ${ }^{1}$, JÖRN-FREDERIK \\ WOTZLAW ${ }^{2}$ AND CYRIL CHELLE-MICHOU $^{2}$ \\ ${ }^{1}$ ETH Zurich \\ ${ }^{2}$ ETH Zürich
}

Presenting Author: adrianna.virmond@erdw.ethz.ch

The Chuquicamata District hosts one of the world's biggest copper resources with more than $130 \mathrm{Mt}$ of $\mathrm{Cu}$ and a mining history of over a century. With several deposits (Chuquicamata, Radomiro Tomic, Ministro Hales, Toki Cluster) of varying metal contents, the district is ideal to investigate the processes that control the size of porphyry copper deposits. The Chuquicamata Intrusive Complex is a megadike composed of three main porphyries. The main and most abundant is the Este granodiorite $^{[1]}$; the Oeste porphyry has similar composition and mineralogy, but in a finer groundmass ${ }^{[1]}$ and the Banco monzogranite is finer grained and more porphyritic than the Este porphyry ${ }^{[1]}$. Previous geochronology suggests that a protracted magmatic history resulted in at least two superimposed hydrothermal events ${ }^{[2]}$, which contributed to the formation of this outsized deposit. Previously reported SHRIMP and LAICPMS dates claim to resolve a 1 Ma gap between emplacement of the Este and the other two porphyries (Oeste and Banco) ${ }^{[2]}$, but dates on individual grains overlap for a timespan of almost six million years. High-precision zircon petrochronology (U-Pb CA-TIMS geochronology in tandem with LA-ICPMS trace element analysis) confirm a protracted period of zircon crystallisation ( $\sim 1 \mathrm{Ma}$ ) within the Este porphyry and resolve an age gap of at least $500 \mathrm{ka}$ between the Este and Banco porphyries. Despite the age difference, these porphyries present similar zircon trace element compositions and Ti-in-zircon temperatures, suggesting a similar source and a protracted thermal history for the source pluton, which might have been necessary to maintain the hydrothermal activity and ultimately form the ore deposit. High-precision zircon petrochronology provides the necessary accuracy and precision to help unravel what controls the formation of behemothian porphyry deposits.

[1] Ossadón et al. (2001) Econ. Geol. 96, 249-270.

[2] Ballard et al. (2001) Geology, 29 (5), 383-386. 